\title{
A IDENTIDADE E OS PROCESSOS DE HIBRIDIZAÇÃO DA CULTURA: RENATO BORGHETTI E AS TRANSFORMAÇÕES DA MÚSICA TRADICIONALISTA
}


A IDENTIDADE E OS PROCESSOS DE HIBRIDIZAÇÃO DA CULTURA: RENATO BORGHETTI E AS TRANSFORMAÇÕES DA MÚSICA TRADICIONALISTA

Resumo: Este trabalho analisa o filme documentário "Renato Borghetti Quarteto-Europa" (2001), e, através dele, buscamos perceber as construções e desconstruções culturais da música gaúcha. Investigamos também qual identidade é apresentada e como a música instrumental foi popularizada. O tradicionalismo e a cultura sulista revelam uma hibridização de elementos culturais distintos. Para percebermos isso, organizamos categorias que apontam os distintos significados presentes no objeto.

Palavras chave: Identidade cultural; Cultura regional; Filme documentário

IDENTIDAD Y PROCESOS DE HIBRIDACIÓN CULTURAL: RENATO BORGHETTI Y LA TRANSFORMACIÓN DE LA MÚSICA TRADICIONALISTA

Resumen: En este trabajo se analiza lo documental "Renato Borghetti Quarteto-Europa” (2001), y a través de él, tratamos de entender las construcciones y deconstrucciones culturales de la música gaúcha. También se investigo que identidad se presenta y como la música instrumental fue popularizada. El tradicionalismo y la cultura del Sur revelan una hibridación de diferentes elementos culturales. Para darse cuenta de esto, organizamos categorías que vinculan los distintos significados presentes en el objeto.

Palabras clave: Identidad cultural; Cultura regional; Documental

THE IDENTITY AND PROCESSES OF CULTURE HYBRIDIZATION: RENATO BORGHETTI AND TRADITIONALIST MUSIC TRANSFORMATIONS

Abstract: This paper analyzes the documentary film "Renato Borghetti Quarteto-Europa" (2001), and through its, we seek to realize the cultural constructions and deconstructions of gaúcha music. We also investigate which identity is presented and how instrumental music was popularized. The traditionalism and Southern culture reveal a hybridization of different cultural elements. To realize this, we organized categories that link the different meanings present in the object.

Keywords: Cultural identity; Regional culture; Documentary film 


\section{INTRODUÇÃO}

As tecnologias da comunicação e informação têm possibilitado às sociedades uma significativa troca cultural através da internet, da telefonia, da televisão e das redes comunicacionais. Com a globalização, o local se transforma em global em instantes. Com isso percebemos um movimento de convergência das culturas e de transformações de muitos aspectos sociais e históricos: "Novos modos de inserção no (e de percepção de) tempo e espaço, com tudo o que implicam de descentralização concentradora de poder e de um enraizamento que leva à hibridização das culturas". (BARBERO, 2003, p.60)

Este trabalho parte de uma pesquisa teórica à luz dos debates advindos dos Estudos Culturais, que se ocupa das "relações entre cultura contemporânea e a sociedade, isto é, suas formas culturais, instituições e práticas culturais, assim como suas relações com a sociedade e as mudanças sociais [...]" (ESCOSTEGUY, 2001, p.21). Trabalhamos, aqui, os aspectos culturais sob o ponto de vista de sua hibridização, que, para Canclini (1998), não significa uma ruptura dos hábitos referentes às identidades locais/regionais, mas que configura um diálogo entre o novo e a tradição, entre desterritorialização e trasnacionalização, constituindo-se como algo em permanente construção. É dessa forma que o objeto de estudo foco deste artigo, documentário Quarteto-Europa, do músico Renato Borghetti, sem perder seu referencial de partida, estabelecido pela identidade gaúcha, se insere no que Canclini (1998) chama de trasnacionalização dos mercados simbólicos.

Para analisá-lo, revemos conceitos como identidade, hibridização, tradicionalismo e cultura regional gaúcha. Nossa metodologia constitui-se numa abordagem qualitativa de caráter experimental de análise dos elementos culturais que figuram o objeto. Esta análise é constituída de cinco categorias discursivas, onde buscamos as marcas da identidade cultural gaúcha, que se hibridiza e se torna "transregional": testemunhalidade, aproximação, autorreferencialidade, atemporalidade e territorialidade/identidade.

\section{UM BREVE HISTÓRICO DOS REALOCAMENTOS DA CULTURA}

Na Inglaterra, no final da década de 1950 e início dos anos 1960, surgiram as primeiras investigações que vieram a constituir o campo dos Estudos Culturais, quando seus autores precursores, Richard Hoggart, Raymond Willians e Edward 
Palmer Thompson, criaram o Centre for Contemporary Cultural Studies (CCCS). Esses autores estavam dispostos a "um olhar interdisciplinar que entende os processos culturais como interdependentes e não como fenômeno isolado; como é a prática usual da maioria das disciplinas" (ESCOSTEGUY, 2001, p.43).

Em um primeiro momento, essas investigações teóricas se concentravam nos receptores e em como as mensagens chegavam até estes. Mas foi através dos Estudos Culturais que muitos outros aspectos da cultura foram explorados, sem, é claro, que o eixo principal das pesquisas (a investigação cultural) fosse perdido. Como aponta Ana Carolina Escosteguy (2001, p.43), o interesse central dos Estudos Culturais está em perceber as inserções entre as estruturas sociais e as formas e práticas culturais. Ou seja, os Estudos Culturais atentam para muitos aspectos que definem uma sociedade, entre eles às características que vão sendo incorporadas, abandonadas, mantidas ou resignificadas nos processos de convergência cultural entre os grupos sociais. Escosteguy e Jacks (2005) explicam como se estabelecem os Estudos Culturais:

Não se constituindo em uma disciplina, mas em um campo de cruzamentos de diversas disciplinas, os Estudos Culturais permitem a combinação da pesquisa textual com a social, na medida em que recuperam a acepção estruturalista sobre a relativa autonomia das formas culturais, situando-as num contexto de forças diversas, bem como do culturalismo, o valor da experiência dos sujeitos para a mudança social. (ESCOSTEGUY; JACKS, 2005, p.38)

Ao ampliar suas observações e estender as percepções de sentido a outros lugares antes não percebidos, os Estudos Culturais se inserem em diversos campos da pesquisa, reestruturando os focos de interesse e entendendo a cultura em um sentido mais amplo. "Os Estudos Culturais estão interessados nas relações entre textos, grupos sociais e contextos ou ainda, em termos mais genéricos, entre práticas simbólicas e estrutura de poder", (ESCOSTEGUY; JACKS, 2005, p.39). É a partir do campo dos Estudos Culturais que, neste artigo, abordamos a interpretação da cultura e dos diferentes aspectos da identidade regional sul-rio-grandense.

Uma identidade cultural, mesmo que restritamente localizada, quando midiatizada, consegue romper as fronteiras territoriais e perpassar outros contextos sociais e históricos. Às vezes buscando manter suas características originais (local/regional), outras vezes negociando novas possibilidades e novas 
maneiras de constituir-se e organizar-se, uma prática cultural- midiatizada - compõe-se com e de outros elementos, hibridizando-se: "A cultura é um processo de montagem multinacional, uma articulação flexível de partes, uma colagem de traços que qualquer cidadão de qualquer país, religião ou ideologia pode ler e utilizar", (CANCLINI, 1999, p.41). Nesse contexto, os indivíduos são atores sociais que se localizam ora no local ora no global, no processo de construção cultural das sociedades.

\section{DA HIBRIDIZAÇÃO À DESTERRITORIALIZAÇÃO DA CULTURA}

Anthony Giddens (2004) nos ajuda a definir as relações entre a sociedade e a cultura. Para o autor, a sociedade "é um sistema de inter-relações que envolve os indivíduos coletivamente" (GIDDENS, 2004, p.22). A cultura, portanto, não acontece fora da sociedade, nem esta pode existir sem cultura. A cultura representa o contexto em que os indivíduos vivem, "engloba tanto os aspectos intangíveis - as crenças, as ideias, os valores que constituem o teor da cultura - como os aspectos tangíveis - os objetos, os símbolos ou a tecnologia que representam esse conteúdo" (GIDDENS, 2004, p.23). Incluímos, assim, seus costumes, suas vestes, maneiras de comunicar, falar, agir e interagir em sociedade.

A cultura foi percebida e definida de diversas formas com o decorrer do tempo. Como afirma José Luiz dos Santos (2006),"a primeira concepção de cultura remete a todos os aspectos de uma realidade social, a segunda refere-se mais especificadamente ao conhecimento, às ideias e as crenças de um povo" (SANTOS, 2006, p.23). Hoje percebemos que um conteúdo cultural vai muito além do que está estabelecido como erudito ou culto, mas como aquilo que está relacionado com às identidades de determinado grupo. Raymond Williams (1992), teórico dos Estudos Culturais, nos ajuda a perceber a cultura como "um sistema de significações"(WILLIAMS, 1992, p.12), compreendida não apenas como as atividades culturais específicas (como agenda de movimentos artísticos ou estéticos), mas também como as demais atividades sociais que os indivíduos realizam. Maria Elisa Cevasco (2001), ao rever o legado teórico de Williams, indica que o autor compreendeu a cultura como

uma prática social que se dá entre as pessoas em situações epecíficas, portanto com significados específicos que podem variar - e efetivamente variam - em diferentes situações sócio-históricas. Trata-se não 
do espaço de cancelamento da luta por mudanças sociais, o espaço onde somos todos igualmente humanos, mas de um espaço fundamental para a política (CESVASCO, 2001, p.130)

Denominamos a cultura não como uma parte, mas como um todo, sendo impossível dissociá-la de práticas sociais e históricas. Como indivíduo e grupo, nossas ações, reações e percepções estão intimamente ligadas ao ambiente no qual estamos inseridos. Isso não significa que pertencemos a uma esfera que nos limita, e sim que nos provoca, nos transforma, na qual somos também atores e agentes. "Definiu-se esta [cultura] como o 'processo integral' pelo qual significados e definições são socialmente construídos e historicamente transformados" (ESCOSTEGUY, 2001, p.22). Ao utilizar o conceito de cultura como um "processo integral", a autora afirma a necessidade de percebê-la como resultado de um processo de convergência, do que é próprio de uma comunidade e daquilo que foi agregado dentro dos contextos sócio-históricos em que ela acontece, visto que

é possível habitar no mundo sem algum tipo de ancoragem territorial, de inserção no local, já que é no lugar, no território, que se desenrola a corporaneidade da vida cotidiana e a temporalidade - a história- da ação coletiva, base da heterogeneidade humana e da reciprocidade, características fundadoras da comunicação humana, pois, mesmo atravessado pelas redes do global, o lugar segue feito do tecido das proximidades e solidariedades (BARBERO, 2003, p.58-59)

Logo, a cultura não deve ser observada somente em sua territorialidade, de fronteiras definidas, mas deve ser entendida como um ambiente de práticas sociais e simbólicas que repercutem no cotidiano e na formação dos indivíduos em diferentes espaços. Como aponta Nilda Jacks (1999), "a cultura regional é um dos fatores de determinação de práticas culturais que diferenciam determinado grupo, fornecendo-lhe uma identidade própria" (JACKS, 1999, p.66). Assim, a identidade referente à figura do gaúcho tradicional foi construída de significações resgatadas de uma cultura rural, elementos como o amor e apego às lidas do campo podem ser citados nesse processo de construção identitária.

Com o passar do tempo, a maneira de viver campesina foi sendo valorizada e tomada como representativa do estado do Rio Grande do Sul. Percebemos que os aspectos regionais, mesmo que por muito tempo restritos ao interior, venceram as limitações geográficas e ocuparam um lugar de cultura de refe- 
rência para a construção da identidade tomadas como pertencentes ao povo gaúcho. Jacks descreve o fenômeno da identidade cultural quando afirma que esta "é uma correlação entre uma cultura que se constitui de normas, mitos, símbolos e imagens, e os indivíduos que já estão estruturados por essas normas, mitos, símbolos e imagens" (JACKS, 2003, p.127).

Nos anos 1960 e 1970, buscando características do gaúcho referentes à Revolução Farroupilha, os Movimentos Tradicionalistas buscaram retratar o cotidiano do gaúcho, bem como o Movimento Nativista, que se preocupou em construir essa identidade através dos festivais de música regional. Nesses eventos de música tradicionalista surgiram muitos compositores hoje consagrados no cenário cultural local. Neles e em suas músicas produzidas, a figura do gaúcho é construída aproximando-se aos ideais farrapos, bem como por seus heróis, lendas e os modos de viver que implicam as tradições gaúchas. Jacks considera que

a cultura regional gaúcha, identificada no movimento Nativista, é um exemplo típico em que o poderio da indústria cultural não foi suficiente para anular uma manifestação regional que mantém relações de significação com a população. (JACKS, 2003, p.29)

Em um primeiro momento, falamos da desterritorialização cultural, quando abordamos o deslocamento da cultura, oriundo de práticas típicas do interior do estado e que hoje vem sendo valorizada em todo o território gaúcho. Como aponta Canclini, “[a] promoção das culturas tradicionais só adquirem sentido e eficácia na medida em que vincula essas tradições às novas condições de internacionalização", (CANCLINI, 1999, p.139). Partindo desse cenário, a cultura e a identidade gaúcha projetam-se de maneira global. Aqui chegamos ao nosso objeto, o documentário sobre a carreira internacional do músico Renato Borghetti, que chama a provocações sobre um processo de desterritorialização ainda maior, um processo de internacionalização da cultura gaúcha.

Cabe ressaltarmos que percebemos no documentário uma representação da cultura gaúcha, principalmente no tangente à música, que se aproxima do fenômeno da hibridização cultural, "o hibridismo está ligado aos movimentos demográficos que permitem o contato entre diferentes identidades: as diásporas, os deslocamentos nômades, as viagens, os cruzamentos de fronteiras" (WOODWARD, 2000, p.87). O artista propõe um novo olhar sob a música gaúcha tradicional, um olhar que parte de uma perspectiva local para a global, dei- 
xando claro que, fundamentalmente, seu trabalho mantém o sentido de suas raízes sulistas e de sua identidade regional.

\section{QUARTETO-EUROPA: UM REGISTRO DA CULTURA NO DOCUMENTÁRIO MUSICAL}

Um documentário, como aponta Ramos (2008), é uma narrativa composta por imagens registradas por câmeras, às vezes acompanhadas de imagens de animação, de ruídos, falas ou músicas, para qual os espectadores olham na busca por aquilo que Ihes é exterior. Como esclarece o autor, "ao contrário da ficção, o documentário estabelece asserções ou proposições sobre o mundo histórico" (RAMOS, 2008, p.22). O mundo em questão não nos remete às grandes narrativas do passado. Embora alguns documentários se interessem em resgatá-las, o mundo histórico ao qual o documentário pode interessar-se, é o mundo das experiências vividas, das singularidades, dos acontecimentos e das sensibilidades dos sujeitos para com as coisas que lhes cercam.

Bill Nichols (2012) organiza os documentários em seis tipos, de acordo com a construção de suas narrativas. São eles os modos poético, expositivo, observativo, participativo, reflexivo e performático. "Quarteto-Europa" se aproxima, em sua linguagem fílmica, ao modo de representação (tipo de documentário) denominado documentário expositivo, que agrupa os elementos do mundo histórico de maneira mais argumentativa, expondo os argumentos a fim de recontar uma história. Esse tipo de documentário enfatiza "a construção de uma sensação de credibilidade" (NICHOLS, 2012, p.144), dá prioridade aos depoimentos (entrevistas) fazendo uso das imagens de maneira a reafirmar, ou ilustrar, aquilo que é construído pela narrativa. Neste tipo de documentário, os depoimentos possuem grande valor, já que neles estão depositados "os saberes" trazidos pelo documentário.

Somos convidados a viajar com os músicos, conhecer os países em que eles estiveram, conhecer os bastidores dos espetáculos, ouvir os comentários da plateia, temos consciência dos problemas enfrentados pela equipe, vemos seus atos e ouvimos suas vozes tal qual elas aconteceram - de fato - no mundo. As imagens são construídas de forma a criar nos espectadores um sentido de "impressão da realidade", de registo do real tal como acontece.

Mais do que uma linguagem expositiva, "Quarteto-Europa” é um filme classificado também como documentário musical, que registra a turnê do artista 
Renato Borghetti e sua banda por alguns países europeus. Essa classificação, “documentário musical”, como aponta Luciano Ramos (2012), foi inaugurada no cinema contemporâneo mundial em 1999 pelo cineasta alemão Wim Wenders, com a obra "Buena Vista Social Clube" - tendo a música como elemento dominante na narrativa. No Brasil, o filme "Samba Riachão", de Jorge Alfredo, marca o início da produção de documentários musicais que buscam entrevistas com compositores e intérpretes, desvendando seu cotidiano, situando as produções musicais nos contextos sociais e históricos em que se desenvolviam e registrando os bastidores das apresentações e os espetáculos. Nesses filmes, é requisito "que a música desempenhe papel fundamental em sua construção estrutural e temática" (RAMOS, 2012, p.129).

Além de mero registro de shows e espetáculos, o documentário musical resgata as percepções dos atores sociais envolvidos sobre si próprios, seu trabalho e o modo como percebem o contexto social em que o realizam. Ele implica questionamentos sobre as práticas culturais (tendo a música como referência), bem como do universo do artista, seja ele íntimo e cotidiano, profissional ou ideológico.

\section{PROCEDIMENTOS METODOLÓGICOS}

Nossa pesquisa parte de um levantamento teórico que nos dá suporte para problematizarmos as inquietações levantadas a partir dos elementos que figuram no documentário. Desta maneira, elaboramos uma análise qualitativa do produto cultural, para posteriormente contextualizá-la no referencial teórico abordado, constituindo assim uma interpretação de nosso objeto. Buscamos elencar as abordagens e estratégias de apresentação da cultura de da identidade regional gaúcha apresentadas pelo documentário. Lúcia Santaella (2010) descreve características metodológicas de um trabalho de natureza experimental na qual nos inspiramos:

Não existe pesquisa experimental sem experimento, isto é, a manipulação deliberada de um aspecto da realidade, dentro de condições anteriormente definidas, a fim de observar se certos efeitos são produzidos. Deste modo, o experimento não pode ser confundido com mera observação ou com experiência. O experimento é uma situação criada em laboratório para observar sob controle a relação entre fenômenos. Controle quer dizer esforços para se eliminar ou reduzir os erros de observação. (SANTAELLA, 2010, p.90) 
Como processo de análise metodológica, estabelecemos cinco categorias onde buscamos as marcas da identidade cultural gaúcha, que se hibridiza e se torna "transregional", a fim de darmos conta das observações empíricas do trabalho. As categorias estipuladas são constituídas em testemunhalidade, aproximação, autorreferencialidade, atemporalidade e territorialidade, pelas quais intentamos completar as nossas percepções diante do objeto.

1 - Testemunhalidade:

A partir do momento em que os músicos relatam suas experiências, vivências pessoais, seus objetivos e as impressões que tiveram dos lugares por onde passaram, detectamos a presença da testemunhalidade. As pessoas entrevistadas também descrevem suas emoções ao ouvir o Quarteto e suas impressões no contato com essa expressão cultural brasileira. São, em sua maioria, depoimentos de estrangeiros maravilhados, ou mesmo surpreendidos com a música brasileira/gaúcha apresentada pelo grupo. Essa categoria é carregada de emoção e subjetividade com marcas bem definidas no decorrer do documentário.

2 - Aproximação:

As marcas dessa categoria ficam evidentes nas apresentações realizadas nas ruas, no contato com as pessoas, nas praças, nos parques e nas casas de espetáculos. Essa estratégia estabelece a ponte entre o produtor e o receptor. A troca com o público constitui marcas de interatividade. Nesse contexto, são mostradas as pessoas, que não os artistas do grupo, tocando o acordeom, contemplados pelos músicos. Aí os papéis se invertem, o artista passa a ser o público. As imagens de bailes e aplausos contribuem para firmar esse contrato de proximidade cultural.

3-Autorreferencialidade:

Essa categoria fica marcada em diversos pontos do filme. Nos momentos em que são revelados os bastidores dos shows e das filmagens, que revelam a composição das músicas, nos relatos de como surgem as melodias e seu processo de produção. Antônio Fausto Neto define autorreferencialidade quando o próprio produto e seus atores revelam as formas de construção, "produzir a própria existência do ambiente midiático, o qual não poderia se constituir de outra maneira a não ser pela evocação de sua referência" (NETO, 2007 p.18). A amizade entre os colegas e os problemas com os instrumentos também são marcas dessa autorreferencialidade. Assim como os bastidores das apresentações e das entrevistas, os músicos frequentemente relatam o trabalho e os 
modos de fazer que direcionam para sua identidade gaúcha e para a cultura na qual se inscrevem.

4 - Atemporalidade:

São utilizados entrevistas, depoimentos, imagens e músicas. Tudo é apresentado de maneira mista, assim como as cidades, que não aparecem na ordem em que foram visitadas pelo grupo. Os lugares são vistos e revistos ao longo da produção, de forma não linear. Durante o documentário, a alternância de cidades e países é marcada por paisagens e estradas, sempre em movimento, remetendo a ideia de ida e de vinda. As placas de trânsito dão a sensação de chegada e partida. Sem um lugar fixo, tanto em relação às viagens quanto de transnacionaliação da cultura gaúcha, que se expande do local para outros lugares, a desterritorialização demonstra ser também uma característica da atemporalidade. Já que o sentido de viagem, construído pelo filme, privilegia tempos e lugares (cidades) diferentes.

5 - Territorialidade/ identidade:

As marcas de territorialidade são constantes no filme e remetem diretamente à construção da identidade gaúcha. Observamos elementos dessa categoria nas vestimentas do gaiteiro, no hábito de tomar o chimarrão (bebida típica gaúcha apreciada por Borghetti em vários momentos da viagem) e na pilcha tradicional masculina'. Quando são citados o churrasco (refeição típica do gaúcho) e algumas expressões recorrentes do sul como "pelea", "esterco" e "bah" 2 , igualmente determinamos como marcas de territorialidade.

As referências ao território europeu também estão bem definidas nas imagens dos pontos turísticos das cidades visitadas, como por exemplo, nos vinhedos da Itália. Elas sinalizam os lugares onde o artistas esteve, marcam outras territorialidades que tiveram acesso à cultura gaúcha. As referências ao território gaúcho podem ser vistas na imagens do artista na beira de um rio na cidade de Ribeirão, no Rio Grande do Sul. São marcas ligadas às identidades regionais, local de origem dos músicos, que deixam claro de onde partiram e para onde retornam.

1 A pilcha é entendida pelo Movimento de Tradições Gaúchas (MTG) como a indumentária composta por bombacha (calça larga presa com botões no tornozelo), camisa, cinto, colete chapéu e faixa.

2 "Pelea”: Disputa, briga, combate; "Bah": refere-se à palavra barbaridade que designa surpresa ou indignação e "esterco": substância orgânica, dejeto de animais. 


\section{A IDENTIDADE DO ARTISTA}

Renato Borghetti surgiu como artista nativista de raiz e, apesar de incorporar características de outros estilos musicais, mantém características da música gaúcha e o estilo de vestir típico da região. Hoje representa a música gaúcha em um cenário musical seleto. Reconhecido como grande instrumentalista, Borghetti conquista espaço em muitos países através do domínio do acordeom, também denominado como "gaita" no Rio Grande do Sul.

O instrumento teve sua origem na China, entrou na Europa pela Rússia, e permite que nele sejam executados diversos estilos musicais. Essa descendência facilitou e permitiu ao músico uma aproximação de sucesso com o público no exterior, como ele mesmo descreve: "A sonoridade do acordeom é familiar para o público europeu, e como partimos de nossas raízes para uma música mais elaborada, uma coisa mais jazzística, a aceitação é total."” A turnê de 2012 na Europa é realizada em parceria com mais três músicos: Daniel Sá nos vioIões, Pedrinho Figueiredo na flauta/sax e Vitor Peixoto nos teclados.

Em suas apresentações, Renato Borghetti não abandona um estilo próprio e inconfundível construído para si. Sua indumentária se apresenta como típica, que remete à identidade sulista e despojada, característica essa ligada diretamente com a forma com que ele produz sua música. Sobre isso, Jacks afirma: "Dos traços apontados (...) como identitários da cultura gaúcha, a música é o meio de expressão mais utilizado para veiculá-los e reforçá-los" (JACKS, 1999, p.92). É essa identidade que carrega o sentimento de pertencimento a um determinado grupo, mesmo que inserido em uma lógica projeção internacional.

Kathrin Woodward (2000) descreve esse processo quando nos diz: "A globalização envolve uma interação entre fatores econômicos e culturais, causando mudanças nos padrões de produção e consumo, as quais, por sua vez, produzem identidades novas e globalizadas" (WOODWARD, 2000, p.20). A globalização potencializa experiências e encontros com outras identidades antes não acessíveis. Corforme explica Barbero, “o processo de globalização que agora vivemos, no entanto, é ao mesmo tempo um movimento de potencialização da diferença e de exposição constante de cada cultura às outras, de

3 Informação disponível na página online do artista: http://www.renatoborghetti.com.br/ portal/php/biografia.php 
minha identidade àquela do outro" (BARBERO, 2003, p.60).

Na construção de sua imagem, o músico não deixa de lado suas origens e assume uma vestimenta simples, customizada na qual ele se apropria de elementos da roupa típica do vestuário gaúcho, fazendo uma releitura contemporânea, que é sua marca registrada: uma camiseta acompanhada de uma bombacha, que por vezes aparece larga, tipicamente gaúcha, e outras justas ao corpo, como algo mais moderno. Sobre as identidades, Stuat Hall esclarece: "Elas têm a ver, entretanto com a questão da utilização dos recursos da história, da linguagem e da cultura para a produção não daquilo que nós somos, mas daquilo que nos tornamos", (HALL, 2000, p.109). Os cabelos pelo ombro ficam espalhados pelo chapéu nos remetendo ao estilo roqueiro. Antes de identificarmos seu rosto nos deparamos com uma identidade marcada e uma música que dificulta uma categorização única, por agregar outros elementos musicais.

A cultura regional precisa ser tratada de forma dialética, ou seja, observando seus pontos de avanço e retrocesso, de rompimento e continuidade, para não cair no equívoco de ser considerada uma manifestação de "autenticidade, merecedora de conservação em museus e casas de cultura" (JACKS,2003, p.21)

Sem abandonar as características da cultura regional, o processo de ressignificação dos elementos culturais ocorre do encontro e do somatório com outros elementos. Nos remetendo ao pensamento de Jacks (1999) quando ela afirma: "a modernidade/ pós modernidade não acaba com o tradicional, mas o transforma, a identidade não pode ser atemporal, mas histórica" (JACKS, 1999, p.36). Nesse sentido percebemos todas as manifestações culturais inseridas nos contextos sociais. Antes de ser um artista, o músico é participante de uma determinada cultura, deixando claro de onde vem, seus hábitos e seu cotidiano.

$\mathrm{Na}$ dualidade entre o que nos torna iguais e o que nos faz diferentes, são estabelecidas relações de poder. "A identidade, tal como a diferença, é uma relação social [...] elas não convivem harmoniosamente, lado a lado, em um campo sem hierarquias; elas são disputadas", (WOODWARD, 2000, p.81). Sobre essa questão, Canclini também nos dá sua contribuição quando afirma que "a identidade, mesmo em amplos setores populares, é poliglota, multiétnica, migrante, feito com elementos de várias culturas" (1999, p.166), resultando na hibridização de diversos elementos.

Finalmente, nos pés, Borghetti calça uma alpargata, calçado tido como típi- 
co do gaúcho, assim como as botas. As apresentações são mescladas de diálogos com o público e a constante movimentação no palco mostra uma sincronia do artista com os outros músicos. Essa comunicação entre os eles nos remete a algo familiar, confortável, que é feito sem a rigidez da norma, mas busca uma apresentação que se pretende leve e emocionante.

\section{A CONSTRUÇÃO E DESCONSTRUÇÃO DA MÚSICA TRADICIONALISTA}

Borghetti incorporou em seu repertório e na produção de suas músicas elementos da música clássica, folclórica e contemporânea. É possível identificarmos uma convergência de estilos tornados por ele híbridos. O acompanhamento musical do violão já uma combinação tradicional com o acordeom. Somam-se a eles o sax, a flauta e o piano. O músico apostou na inserção de outros instrumentos para compor um cenário melódico que, mesmo definido em suas raízes tradicionalistas, pudesse dialogar com outros ritmos, como o erudito, o jazz e o folk.

O processo de hibridização coloca no mesmo plano as diversas manifestações da cultura contemporânea, rompendo as fronteiras estabelecidas pela lógica da modernidade, em que o culto deveria estar nos museus e o popular nas praças e feiras (JACKS, 1999, p.34)

Na musicalidade de Borghetti, a hibridização surge da simplicidade harmônica da melodia gaúcha aliada com o erudito e requintado estilo da música clássica e do jazz. Desta maneira, o artista converge as fronteiras do nobre e do popular, denominando isso como apenas “música boa". Reconhecemos no estilo, na melodia e na gaita elementos que compreendem a tradição da região sul, do mesmo modo, a Europa retoma e aprecia a música instrumental e o acordeom como algo também familiar. Jacks conclui que "o tradicional e o moderno, portanto, já não sofrem uma oposição tão evidente, pelo contrário, convivem em um mesmo cenário social" (JACK,1999, p.34).

Na música tradicionalista misturada com a instrumentalização da música clássica se constitui toda a popularidade do artista, mostrando um movimento de hibridização da cultura gaúcha com elementos que historicamente não lhe pertenciam. O público pode ser qualquer um, o gaúcho, o europeu, o jovem, o idoso. O ritmo é culto e popular. Assim, o músico constrói e reconstrói, através de sua música, nuances da cultura gaúcha. Ao mesmo tempo em que firma raiz em suas tradições, ele explora as múltiplas faces e possibilidades de uma pro- 
dução cultural globalizada. Renato Borghetti leva, assim, algo muito peculiar e regional para um espaço globalmente localizado.

O Rio Grande do Sul historicamente foi construído pela imigração de povos europeus, possuindo características de italianos, alemães, espanhóis, dentre outros. A Europa parece estar bem familiarizada com o estilo musical que o artista desenvolve. Isso é um aspecto que permitiu uma grande empatia com a música apresentada por Borghetti. A desterritorialização da cultura no filme percorre um caminho inverso. Foi grande a influência dos povos europeus na colonização da região sul do país, mas agora, são os elementos da cultura gaúcha que migram para a Europa, movimento permitido pela circularidade da informação diante do global.

É disso que vive um indivíduo e uma comunidade, de traços que lhe são próprios e reconhecidos facilmente e daquilo que lhe foi e é agregado por outros elementos. As novas estruturas, os novos formatos e modos de fazer não excluem o antigo, apenas retomam-no de outras formas.

\section{IDENTIDADE GAÚCHA CONSTRUÍDA ATRAVÉS DO DOCUMENTÁRIO}

Para que possamos compreender os elementos culturais locais da cultura gaúcha, principalmente a música, que se expandem territorialmente através das apresentações do cantor Renato Borghetti por vários países da Europa, descrevemos algumas cenas do documentário, buscando demonstrar como é construído, na narrativa fílmica, esse processo.

No filme "Quarteto-Europa", realizado de julho de 2010 e abril de 2011, as apresentações são mescladas com narrações, entrevistas e clips. O músico, através de uma narração em off, mostra para o público a satisfação que tem com o seu trabalho e sua relação com a gaita, em suas falas, a "extensão do [seu] corpo". As imagens sobrepostas à fala revelam sua identidade e seu jeito de viver tomados como referentes ao jeito gaúcho. A partir disso as imagens já revelam o músico na Europa, os festivais e as apresentações. Quando Renato Borghetti aparece tomando um chimarrão, como marca de territorialidade, o filme constrói um sentido de projeção do gaúcho para além das fronteiras do estado, ou do país.

Em uma entrevista, Borghetti explica sua origem e em seguida duas produtoras europeias descrevem um pouco como a região recebe o que é produzido no Brasil. O povo reconhece o samba, a música popular brasileira e a influência 
europeia na colonização do sul do Brasil em sua música, apesar de não distinguirem bem os ritmos sulistas. $O$ contato com a gaita foi interessante no sentido melódico e na forma como Borghetti se apresenta referindo-se ao figurino, relata uma produtora.

"A coerência do meu trabalho, a meu ver, sempre vai ser buscar o novo, o moderno e o contemporâneo, mas sem perder a origem, a essência e a raiz do trabalho", revela Renato Borghetti. A descrição do músico casa perfeitamente com o conceito de hibridização proposto na pesquisa, através da agregação e transformação da cultura. A imagem da estrada configura a partida e as placas de trânsito indicam sua chegada à Alemanha. Outra melodia é colocada ao fundo das imagens e o show divide espaço com a aparição dos bastidores. Borghetti é visto em um momento de concentração na coxia até o momento de subir ao palco, são imagens que reforçam a ideia da autorreferencialidade.

Na Eslovênia uma pessoa da plateia descreve a forte e densa tradição incorporada na música. A partir daí, o quarteto já está na França e o produtor musical Airton dos Anjos conta como surgiu a ideia de reunir vários músicos para uma gravação no ano de 1996. Diante de uma passagem desordenada por muitos lugares da Europa, percebemos a construção de uma narrativa que aponta a categoria de atemporalidade levantada em nossa pesquisa.

Na Alemanha as pessoas descrevem a sensação de ouvir a música instrumental do quarteto. A melodia termina com imagens do show em Utrecht, na Holanda. Um holandês que estava presente explica que o encantamento pela música é devido não apenas aos aspectos familiares e às características europeias, mas justamente por possuir um elemento diferente. Essa afirmação configura a testemunhalidade do receptor.

Uma italiana diz que não esperava ouvir uma música brasileira dessa maneira, algo moderno e internacional. Com a música, Borghetti interage com as pessoas e se mostra muito à vontade quando aplaude uma jovem holandesa tocando acordeom. Assim percebemos a aproximação dos músicos para com o público. Um jornal local anuncia a apresentação do Quarteto. A manchete coloca que o músico traz em seu espetáculo o samba, o jazz e o tango. Fica claro aqui como a música brasileira é representada, o samba, como elemento popular, o jazz, como moderno, e uma referência ao tango argentino, pela proximidade territorial e cultura da Argentina com a região sul. Borghetti garante que o que eles virão será bem diferente. Em Trento, uma italiana diz que a música surpreende porque traz em si algo novo e diferente. 
Quando desembarca em um parque em Bruxelas, Borghetti compara o local visitado com o parque da Redenção, ponto turístico de Porto Alegre, capital do Rio Grande do Sul, estabelecendo novamente um vínculo de territorialidade. Uma cidadã local descreve a música do quarteto como algo de muita emoção e alegria. Outro morador diz que nunca imaginou alguma coisa desse tipo vinda do Brasil.

Junto à placa de Borghetto, na Itália, o músico começa a contar um pouco da sua história, características essas que marcam a autorreferencialidade. Em sequência, algumas pessoas se apresentam com o sobrenome Borghetti em comum. No vinhedo, Borghetti toca a gaita e interage com as pessoas da localidade, mantendo o sotaque marcado e o maneira despojada de agir. Os habitantes de Borghetto contam a história da família que, por muitos anos, foi a mais rica da região, trabalhando com atividades comerciais.

Na Hungria, um casal de meia idade define como fantástica a apresentação. Na Finlândia, o quarteto toca em um lago às três horas da manhã, à luz do dia. Borghetti explica que durante a maior parte do ano não anoitece na região. Com as paisagens retornamos à Itália, onde um italiano apresenta a Borghetti o Museu Internacional do Acordeom. Em seguida, o músico é convidado a conhecer a fábrica Scandalli, a mais famosa fábrica de acordeons do mundo. Na Bélgica, sua música é vista com características individuais, modernas e com solos que fazem referência ao jazz. Um alemão revela a experiência de sentir a melodia.

$\mathrm{Na}$ Inglaterra as pessoas relatam que já conheciam a música brasileira, mas não a música que está sendo apresentada por eles. Os problemas com os instrumentos durante a viagem também são revelados para tornar a representação da viagem mais real, documental e autorreferencial.

Uma placa na Barra do Ribeiro indica o caminho de volta pra casa, concluindo assim as marcas de territorialidade. Já no Rio Grande do Sul, Renato Borghetti conta um pouco sobre seu projeto "Fábrica de Gaiteiros" e seu empenho em formar músicos. Nas imagens percebemos crianças aprendendo a manusear o instrumento e nas roupas típicas a cultura tradicionalista gaúcha sendo referenciada.

A última parte do filme retrata a cultura tradicionalista no seu território. Renato Borghetti sobe ao palco, em um Departamento de Tradições Gaúchas (DTG), para apresentar o resultado do seu projeto com os gaiteiros mirins. Nessa apresentação é revelado muito mais do que seu trabalho com a música re- 
gional, mas sim sua preocupação em manter fomentada a cultura tradicionalista gaúcha, bem como a identidade daqueles que nela se identificam.

\section{CONSIDERAÇÕES FINAIS}

Durante o processo de interpretação do objeto, estabelecendo categorias analíticas que nos auxiliaram a compreender os elementos que apontam a uma hibridização da cultura construída através da narrativa do documentário. A música tradicionalista gaúcha, mesmo fortemente vinculada à região sul do Brasil, conseguiu conquistar espaço e obter sucesso no exterior devido tanto a um processo de hibridização de elementos, resultado de um movimento de construção e desconstrução musical, quanto de projeção internacional. Ela foi traduzida em algo novo, moderno e contemporâneo, possível pelos movimentos oriundos da globalização e da circularidade da informação. Esse processo não significou uma ruptura com o tradicional, mas ao contrário, uma transformação e agregação de características de outros modos de ser e de outros elementos culturais. O tradicional e o moderno, quando convergem, não necessariamente perdem suas características de origem.

Ao somar ao tradicionalismo elementos eruditas, Renato Borghetti contribuiu para a construção de uma música que, ao mesmo tempo, apresenta características locais mas transpostas pela globalização. As transformações são formas de vivenciar, resgatar e perpetuar a cultura, de maneira que os elementos sociais e históricos não se percam, mas se transformem em algo genuinamente particular e ao mesmo tempo global.

A figura de Borghetti nos permite partirmos para uma nova releitura da cultura gaúcha: o cabelo lembra o rock and roll, as bombachas estreitas e as camisetas largas dão à sua imagem um estilo mais despojado. As marcas do híbrido estão presentes tanto nele, nas formas corporalizadas, sua vestimenta e modo de agir, quanto em sua produção musical. O processo de desterritorialização cultural permite que novos traços identitários surjam do encontro e da transformação entre elementos culturais distintos.

\section{REFERÊNCIAS}

BARBERO, Jesús-Martín. Globalização comunicacional e transformação Cultural. In: MORAES, Dênis de (org.). Por Uma Outra Comunicação: Mídia, mundialização cultural e poder, Rio 
de Janeiro: RECORD, 2003, p. 57-86.

CANCLINI, Nestor García. Culturas Híbridas: estratégias para entrar e sair da modernidade. São Paulo: Edusp, 2.ed,1998.

Nestor García. Consumidores e cidadãos: conflitos multiculturais da globalização. 4.ed. Rio de Janeiro: Editora UFRJ, 1999.

CANTO GAUDÉRIO. Dicionário gaudério. Disponível em: http://cantogauderio.com.br/index. php/costumes-dos-gauchos/dicionario-gauderio.html Acessado em: 11. nov. 2012.

CEVASCO, Maria Elisa. Para ler Raymond Williams. São Paulo: Paz e Terra, 2001.

ESCOSTEGUY, Ana Carolina; JACKS, Nilda. Comunicação e recepção. São Paulo: Hacker, 2005..

. Cartografia dos estudos culturais: uma versão latino-americana. Belo Hori-

zonte: Autêntica, 2001.

GIDDENS, Anthony. Sociologia. Lisboa: Fundação Calouste Gulbenkian, 2004.

HALL, Stuart. Quem precisa da identidade? DA SILVA, Tomaz Tadeu (org.) In: Identidade e diferença: a perspectiva dos estudos culturais. Petrópolis, RJ: Vozes, 2000, p. 103-133.

JACKS, Nilda. Mídia nativa: indústria cultural e cultura regional. Porto Alegre: Ed. Universidade/UFRGS, 2003.

. Querência: Cultura regional como mediação simbólica - um estudo de re-

cepção. Porto Alegre: Ed. Universidade/UFRGS, 1999.

JOHNSON, Richard; ESCOSTEGUY, Ana Carolina; SCHULMAN, Norma. O que é, afinal, Estudos culturais? Belo Horizante: Autêntico, 2004.

MICHAELIS. Dicionário de Português On-line. Disponível em: http://michaelis.uol.com.br/ moderno/portugues/index.php?lingua=portugues-portugues\&palavra=esterco Acessado em: 11. nov. 2012.

MTG - Movimento Tradicionalista Gaúcho. Diretrizes para a pilcha gaúcha, 2011. Disponível em: http://www.mtg.org.br/DIRETRIZES\%20PARA\%20AS\%20PILCHAS.pdf Acessado em: 11. nov. 2012.

NETO, Antônio Fausto. Enunciação, auto-referencialidade e incompletude. Revista FAMEcOS. Porto Alegre, $\mathrm{n}^{\circ}$ 34, 2007.

NICHOLS, Bill. Introdução do documentário. Campinas, SP: Papirus, 2012.

RAMOS, Fernão Pessoa. Mas afinal... o que é mesmo o documentário? São Paulo: Senac, 2008.

RAMOS, Luciano. Como explicar o ímpeto do documentário musical brasileiro? Doc On-line, n. 12, agosto de 2012, p.127-150.

SANTAELLA, Lúcia. Comunicação e pesquisa. São José do Rio Preto, SP: Bluecom Comunicação, 2010.

SANTOS, José Luiz Dos. O que é cultura. São Paulo: Brasiliense, 2006. 
WILLIAMS, Raymond. Cultura. São Paulo: Paz e Terra, 1992.

WOODWARD, Kathryn. Identidade: uma introdução teórica conceitual. DA SILVA, Tomaz Tadeu (org.) In: Identidade e diferença: a perspectiva dos estudos culturais. Petrópolis, RJ: Vozes, 2000, p. 07-68.

RECEBIDO EM: 28/10/12

ACEITO PARA PUBLICAÇÃO: 23/11/12

\section{Tiane Dias Canabarro}

Possui graduação em Comunicação Social, habilitação em Jornalismo, pelo Centro Universitário Franciscano (2010). Atualmente é aluna do curso de especialização, Comunicação e Projetos de Mídia, pela mesma instituição.

\section{Alisson Machado}

Possui graduação em Comunicação Social, habilitação em Jornalismo, pela Universidade Federal de Santa Maria (2011). Atualmente é aluno de graduação do curso de Ciências Sociais e do Programa de Pós-Graduação em Comunicação, em nível de mestrado, pela mesma instituição. 